\title{
Nitrogen Accumulation and Fertilizer Use Efficiency by Grapevines in Short- season Growing Areas
}

\author{
Eric J. Hanson and G. Stanley Howell \\ Department of Horticulture, Michigan State University, East Lansing, \\ MI 48824-1325
}

\section{Additional index words. Vitis labrusca}

\begin{abstract}
Mature 'Concord' vines (Vitis labrusca L.) were excavated at 2- to 4-week intervals through the season to study seasonal changes in vine $\mathbf{N}$ concentration. Vine $\mathbf{N}$ content began increasing 2 weeks after budbreak, increased most rapidly from mid-May to mid-July, and declined between fruit maturation and the beginning of leaf senescence. Vine $\mathrm{N}$ content was lowest at budbreak $(18 \mathrm{~g})$ and maximum at fruit maturity $(75 \mathrm{~g})$. This change represented a net accumulation of $57 \mathrm{~g} \mathrm{~N} / \mathrm{vine}$ or $77 \mathrm{~kg} \mathrm{~N} / \mathrm{ha}$. In a separate study, 'Seyval blanc' vines were treated with double ${ }^{15} \mathrm{~N}$-labeled ammonium nitrate at either budbreak or bloom. Labeled $\mathbf{N}$ was applied as a spray beneath vines to simulate a broadcast vineyard application. Vines were excavated when leaves began to senesce in October, partitioned into various components, and analyzed by mass spectrophotometry to determine fertilizer-derived $N$ content. Vines had recovered statistically similar percentages of fertilizer $N$ applied at budbreak $(7.1 \%)$ and bloom $(10.6 \%)$. The low recovery of fertilizer $\mathbf{N}$ likely resulted from the method of fertilizer application, the presence of a competitive grass sod between the rows, and relatively high native soil $\mathrm{N}$ levels.
\end{abstract}

Efficient use of fertilizer $\mathrm{N}$ in crop production is increasingly important. Low recovery of applied $\mathrm{N}$ by crops (low efficiency) may contribute nitrate to surface or groundwater, and necessitate the use of higher fertilizer rates to supply plants with sufficient N. High nitrate levels in groundwater are increasing concerns in grape production areas of California (Anton et al., 1988) and Germany (Schaller, 1991).

The $\mathrm{N}$ required for the annual growth of perennial plants, such as grapevines, may be absorbed during the current season or absorbed during previous seasons and stored in perennial tissues. The current-season absorption, measured by excavating mature vines at intervals during the season, was 61 to $75 \mathrm{~g} \mathrm{~N} /$ vine (68 to $84 \mathrm{~kg} \cdot \mathrm{ha}^{-1}$ ) for 'Thompson Seedless' (Vitis vinifera L.) in California (Williams, 1991) and $70 \mathrm{~kg} \mathrm{~N} / \mathrm{ha}$ in 'Riesling' vineyards in Germany (Lohnertz, 1991). Mature 'Cabernet Sauvignon' vines in California accumulated $16 \mathrm{~g} \mathrm{~N} /$ vine $\left(18 \mathrm{~kg} \cdot \mathrm{ha}^{-1}\right)$ between bloom and fruit maturity (Williams and Biscay, 1991).

The current-season $\mathrm{N}$ absorption also has been estimated by measuring the $\mathrm{N}$ content of leaves, new shoots, and fruit. Although these estimates assume no net change in the $\mathrm{N}$ content of perennial vine parts (trunks, roots), values are often similar to estimates based on whole-vine measurements. Based on the annual $\mathrm{N}$ accumulation in leaves, shoots, and

Received for publication 7 Nov. 1994. Accepted for publication 8 Mar. 1995. Acknowledgement is made to the Michigan Grape and Wine Industry Council and the Michigan Agricultural Experiment Station for support of this work. The cost of publishing this paper was defrayed in part by the payment of page charges. Under postal regulations, this paper therefore must be hereby marked advertisement solely to indicate this fact. fruit, Williams (1987b) estimated that 'Thompson Seedless' vines required $75 \mathrm{~g}$ N/vine (84 $\mathrm{kg} \cdot \mathrm{ha}^{-1}$ ) annually, whereas 'Cabernet Sauvignon' vines required only $24 \mathrm{~g} \mathrm{~N} /$ vine or $27 \mathrm{~kg} \mathrm{~N} / \mathrm{ha}$ (Williams and Smith, 1991). The fruit, leaves, and shoots of 'Chenin blanc' vines accumulated a total of $12 \mathrm{~g} \mathrm{~N} / \mathrm{vine}(27 \mathrm{~kg}$ N/ha) (Conradie, 1986).

Nitrogen absorption and use by grapevines vary during the season. Absorption is relatively slow between budbreak and bloom, and the $\mathrm{N}$ demand of shoots and leaves at this time is met by current-season absorption $(80 \%)$ and reserves acquired the previous season (Conradie, 1991). Nitrogen absorption is most rapid between bloom and veraison (Lohnertz, 1991; Williams, 1987a, 1978b, 1991; Williams and Biscay, 1991) and generally meets the demands of the rapidly growing shoots and fruit (Conradie, 1991). Between veraison and harvest, the rate of $\mathrm{N}$ absorption may decline (Lohnertz, 1991; Williams, 1991). Clusters accumulate $\mathrm{N}$ rapidly at this time (Conradie, 1991; Williams, 1987b). From harvest to leaf fall, trunks and roots usually accumulate the $\mathrm{N}$ reserves that support early growth during the following spring (Conradie, 1991). These reserves may be supplied from $\mathrm{N}$ that is remobilized from leaves and shoots, and from current absorption.

The efficiency of fertilizer use (proportion of applied $\mathrm{N}$ that is absorbed by grapevines) has been studied by tracing ${ }^{15} \mathrm{~N}$-enriched fertilizer. Williams (1991) compared the $\mathrm{N}$ use efficiency by mature 'Thompson Seedless' vines in California. Trickle-irrigated vines were fertilized to simulate injection through the irrigation system either once in May or on 10 dates from April to August. Furrow-irrigated vines received fertilizer in the furrow in May. Drip-irrigated vines fertilized in May recov- ered the most fertilizer $\mathrm{N}$ after one season (42\%), followed by drip-irrigated vines receiving multiple applications ( $34 \%$ of $\mathrm{N}$ ), and then furrow-irrigated vines (14\%).

Conradie (1986) compared the $\mathrm{N}$ use efficiency by 'Chenin blanc' vines on a sandy soil and a sandy loam soil. Vines received ${ }^{15} \mathrm{~N}$ enriched fertilizer in the spring or fall and were excavated the following spring. The percent recovery of fertilizer $\mathrm{N}$ was higher on the sandy soil (50\%) than the sandy loam (30\%). Spring and fall fertilization resulted in the same recovery, indicating that vines readily absorb $\mathrm{N}$ in the fall in regions where vines are active for several months after harvest.

Studies of annual $\mathrm{N}$ absorption and fertilizer use efficiency in grapes have been conducted on $V$. vinifera cultivars, usually in regions with long growing seasons. We found no similar information for $V$. labrusca or French-American hybrid cultivars that are grown under the short seasons of Michigan where fall leaf senescence can occur shortly after harvest. These studies were conducted to describe the seasonal pattern and total quantity of $\mathrm{N}$ absorbed by grapevines under Michigan conditions. We also were interested in comparing the recovery of fertilizer $\mathrm{N}$ applied at budbreak or at bloom.

\section{Materials and Methods}

Seasonal $N$ absorption (Expt. 1). Seasonal $\mathrm{N}$ absorption was studied in a 1981 planting of 'Concord' located on a Kalamazoo sandy loam soil at the Clarksville Horticultural Experiment Station (CHES) in Clarksville, Mich. Vines were planted $2.4 \mathrm{~m}$ apart in rows $3.0 \mathrm{~m}$ apart and were trickle-irrigated and balancepruned. A permanent grass strip was maintained between the rows, and a $1.5-\mathrm{m}$-wide strip within the row was kept vegetation-free with use of herbicides. The vineyard was fertilized annually with $90 \mathrm{~kg} \mathrm{~N} / \mathrm{ha}$ at budbreak in the spring.

Forty vines of similar size were selected in two adjacent rows and randomly assigned one of eight sampling dates (five vines per date). Sampling was at 2- to 4-week intervals between budbreak (29 Apr.) and the beginning of fall leaf abscission (28 Sept.) during 1991. On each date, the soil was removed and roots collected from a $1.0-\mathrm{m}$ square area, $0.5 \mathrm{~m}$ deep, at the base of each vine. Aboveground parts were separated into wood (trunk, cordons, and previous-year's canes), canes (current-season canes and leaves), and fruit. Tissues were placed in forced-air driers at $32 \mathrm{C}$ for 1 to 8 weeks until sample weight became constant.

Dry tissues were weighed. Wood and root tissues were preground using a hammer-mill pulverizer (American Pulverizer Co., St. Louis). Representative samples of all tissues were finely ground in a Wiley mill to pass a 1$\mathrm{mm}$ mesh. Total tissue $\mathrm{N}$ concentrations were measured with a flow injection analyzer model Quickchem (Lachat Instruments, Mequon, Wis.), using Kjeldahl digestion followed by ammonium analysis.

Labeled $N$ recovery (Expt. 2). Recovery of 
${ }^{15} \mathrm{~N}$-labeled fertilizer $\mathrm{N}$ was measured in a second study using 'Seyval blanc' vines at the CHES. Vines were planted in 1983 at a $2.4 \times$ 3.0-m spacing on a Kalamazoo sandy loam soil. A permanent 1.4-m-wide sod strip was maintained between rows, and the 1.6-m-wide area beneath vines was kept vegetation-free with the use of standard herbicides.

Vines were balance-pruned in Apr. 1992, using a 15 plus 10 formula (15 buds retained for the first $0.45 \mathrm{~kg}$ of cane prunings, 10 buds for each additional $0.45 \mathrm{~kg}$ ), and pruning weights (vine size) were recorded. Eight vines were blocked as pairs according to size and assigned one of two treatments. Treatments included fertilization at budbreak (25 Apr. 1992) or full bloom (16 June 1992). Vines received $100 \mathrm{~g} \mathrm{NH}_{4} \mathrm{NO}_{3}$, in which both $\mathrm{N}$ atoms were enriched to 10 atom percent ${ }^{15} \mathrm{~N}$ (ICON Services, Mt. Marion, N.Y.). The fertilizer was dissolved in 2 liters water and applied with a backpack sprayer to a $2.4 \times 3.0$ $\mathrm{m}$ area around each vine. Vines were flowercluster-thinned on 16 June to retain only the basal cluster. Flower clusters were dried and later weighed, and those from vines receiving fertilizer at budbreak were retained for later analysis. Ripe fruit were harvested on 9 Sept. Fresh fruit weights were recorded and representative samples were frozen. Subsamples were later freeze-dried and ground in a Wiley mill in preparation for $\mathrm{N}$ analysis.

Aboveground vine parts were harvested on 18 Oct. 1993, when leaves were becoming senescent. Trunks and cordons, shoots, and leaves were separated and weighed. Fertilizer $\mathrm{N}$ recovery by the vegetation in the sod strip was measured by removing two $0.1-\mathrm{m}^{2}$ areas, $0.2 \mathrm{~m}$ deep, within the sod strip on either side of vines. Soil was rinsed away and plant roots and aboveground parts were retained for $\mathrm{N}$ analyses. Grapevine roots were excavated with a backhoe on 29 Oct. Roots were collected from a $3 \times 2.4-\mathrm{m}$ area around each vine, to a depth of $0.8 \mathrm{~m}$. Soil was sieved through a 2.5 $\times 1.3-\mathrm{cm}$ mesh screen to separate the roots from the soil. Roots were washed to remove attached soil. All tissues were placed in a forced-air drier at 32C for 4 weeks and then weighed.

Dry tissues were first preground with a model 4 Wiley Mill, which accommodated larger woody tissues, then finely ground in a standard Wiley mill to pass a $1-\mathrm{mm}$ mesh screen. Total tissue $\mathrm{N}$ concentrations were measured as described for Expt. 1. Subsamples of tissues were finely pulverized in a mortar and pestle in preparation for $\mathrm{N}$ isotope analyses. Percent atom abundance of ${ }^{15} \mathrm{~N}$ was determined with a Tracer Mass (Europa Scientific, Cheshire, England) mass spectrometer. The atom percent excess was calculated as the difference between the atom percent ${ }^{15} \mathrm{~N}$ (sample) and atom percent ${ }^{15} \mathrm{~N}$ (native). The percent $\mathrm{N}$ derived from fertilizer (dff) was then calculated: percent $\mathrm{N} \mathrm{dff}=($ atom percent excess/atom percent fertilizer) $\times 100$.

Vine $\mathrm{N}$ content was calculated from the $\mathrm{N}$ concentrations and dry weights of vine parts. The area of vineyard floor vegetation associated with each vine was equal to the in-row vine spacing $(2.4 \mathrm{~m})$ times the sod strip width $(1.3 \mathrm{~m})$, i.e., $3.1 \mathrm{~m}^{2}$ per vine. This figure was used to express the dry weight and $\mathrm{N}$ content of vineyard floor vegetation on a per vine basis.

\section{Results}

Seasonal $N$ absorption. The dry weight of 'Concord' vines increased from $2.8 \mathrm{~kg} /$ vine at budbreak to a maximum of $9.1 \mathrm{~kg}$ at fruit harvest (Fig. 1). At fruit maturity, new shoots and leaves, fruit, trunk and cordon, and roots contained $39 \%, 32 \%, 17 \%$, and $11 \%$ of vine dry matter, respectively.

'Concord' vines contained $18 \mathrm{~g} \mathrm{~N}$ at budbreak, $75 \mathrm{~g}$ at fruit maturity, and $43 \mathrm{~g}$ in late September when leaves were becoming senescent (Fig. 2). At fruit maturity, when vine N content was the highest, shoots and leaves, fruit, roots, and trunk and cordons contained $53 \%, 28 \%, 11 \%$, and $8 \%$ of total vine $\mathrm{N}$, respectively.

Labeled $N$ recovery. 'Seyval blanc' vines treated with ${ }^{15} \mathrm{~N}$-labeled fertilizer at bloom had higher leaf and root dry weights than vines treated at budbreak (Table 1). Bloom-treated vines also contained more total $\mathrm{N}$ in leaves and roots than vines fertilized at budbreak.

Fertilizer N accounted for $5.8 \%$ to $6.5 \%$ of total vine $\mathrm{N}$ at the end of the season (Table 1), and this percentage was not affected by time of application. Fertilizer $\mathrm{N}$ accounted for the highest percentage of total tissue $\mathrm{N}$ in mature fruit (mean $7.4 \%$ ), with the least in the trunk and cordons (mean $4.1 \%$ )

Total fertilizer-derived $\mathrm{N}$ per vine averaged 2.49 and $3.72 \mathrm{~g}$ for budbreak and bloom treatments, respectively, and was not affected by application time (Table 1). These levels represent $7.1 \%$ and $10.6 \%$ of applied fertilizer. However, the trunk and cordons and leaves of vines fertilized at bloom contained more fertilizer-derived $\mathrm{N}$ than the same parts of vines fertilized at budbreak. The amount of fertilizer $\mathrm{N}$ in the vegetation on the vineyard floor following applications at budbreak (3.61 $\mathrm{g} / \mathrm{vine})$ or bloom $(5.17 \mathrm{~g})$ was similar. The total amount of fertilizer-derived $\mathrm{N}$ in all plant tissue (vine and vineyard floor vegetation) was significantly higher $(P \leq 0.05)$ when fertilizer was applied at bloom $(8.89 \mathrm{~g})$ than when applied at budbreak $(6.1 \mathrm{~g})$. These quantities represent $25 \%$ and $17 \%$ of applied $N$, respectively.

\section{Discussion}

Mature 'Concord' vines accumulated a total of $57 \mathrm{~g} \mathrm{~N}$ (76.7 kg N/ha) and $6.3 \mathrm{~kg}$ dry weight/ vine in fruit, shoots, and leaves between budbreak and fruit maturity. These vines averaged $1.6 \mathrm{~kg}$ of cane prunings before this study and were more vigorous than typical commercial 'Concord' vineyards in Michigan. Lessvigorous vines would likely accumulate less dry matter and N. Dry-matter accumulation by $V$. vinifera vines has ranged from $4.6 \mathrm{~kg}$ in 'Pinot noir' in Switzerland (Wermelinger and Koblet, 1990) to $7.7 \mathrm{~kg}$ in 'Thompson Seedless' in California (Williams, 1987a). Similar measurements of the annual $\mathrm{N}$ accumulation by $V$. vinifera ranged from 61 to $75 \mathrm{~g} \mathrm{~N}$ /vine (Lohnertz, 1991; Williams, 1991).

'Concord' vines absorbed $\mathrm{N}$ most rapidly from 2 weeks after budbreak to fruit harvest

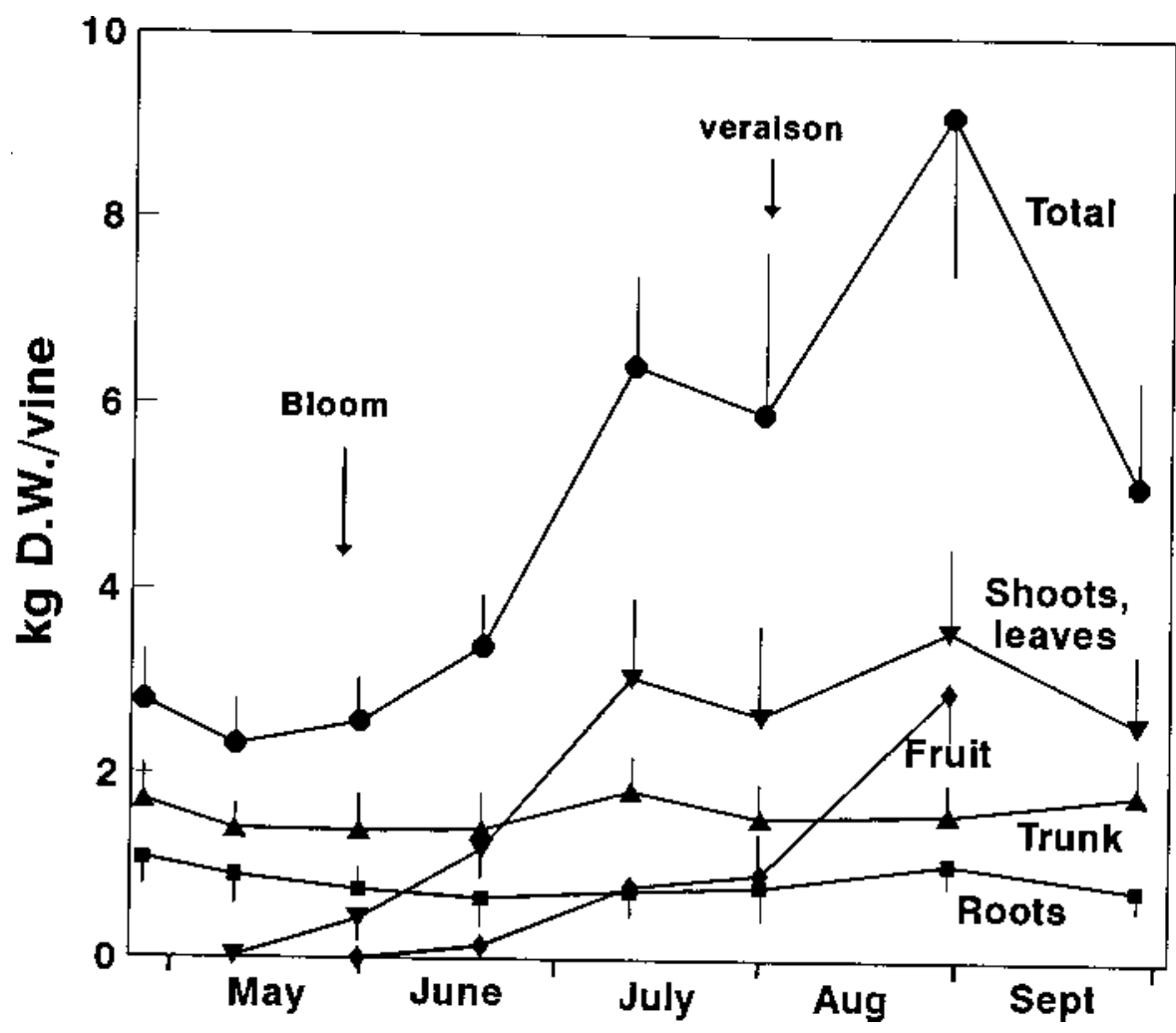

Fig. 1. Seasonal changes in the dry-matter content of mature 'Concord' grapevines. Data are means of six vines. Vertical lines represent one standard error. 


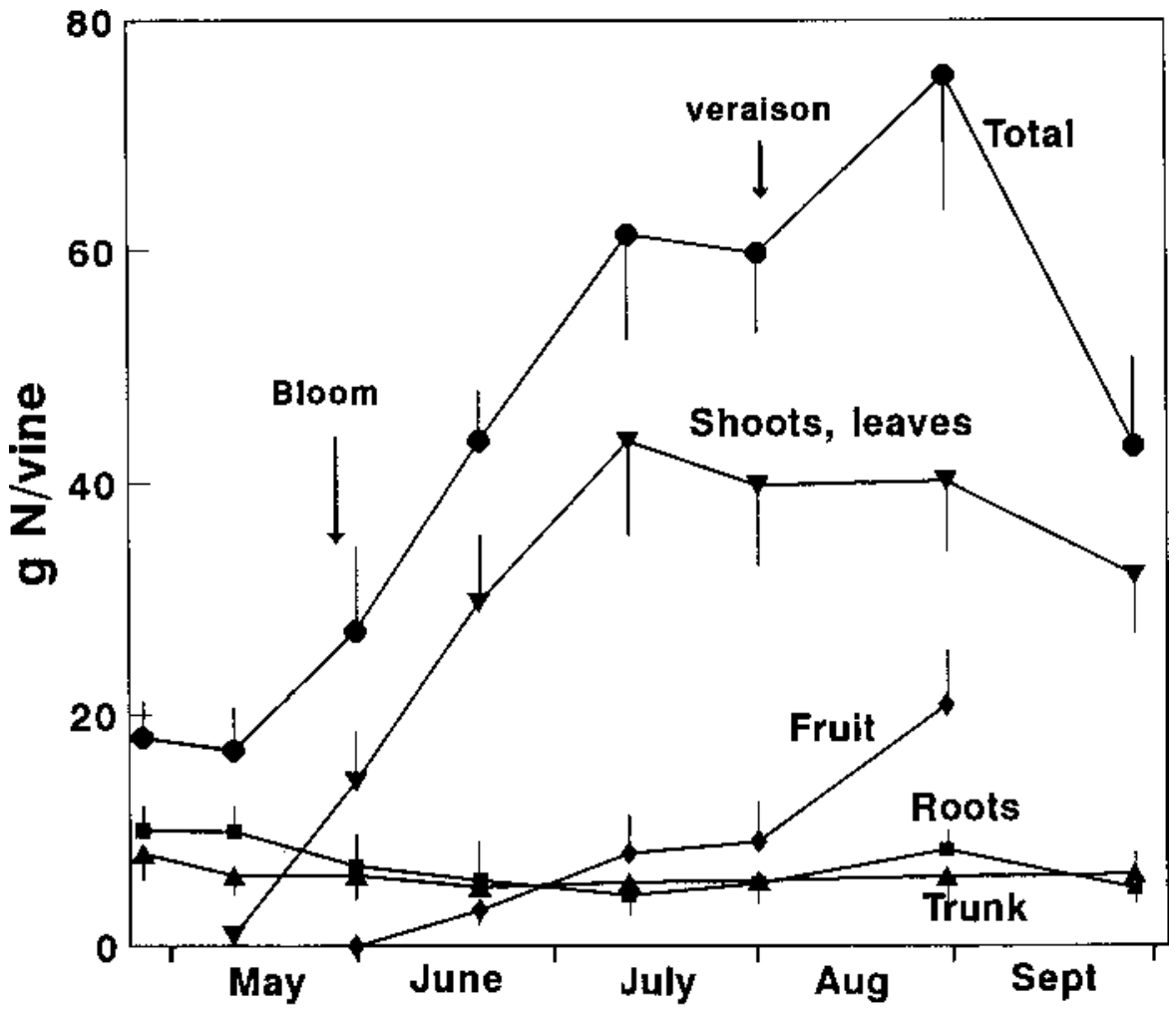

Fig. 2. Seasonal changes in the $\mathrm{N}$ content of 'Concord' grapevines. Data are means of six vines. Vertical lines represent one standard error.

Table 1. Effect of time of ${ }^{15} \mathrm{~N}$-labeled ammonium nitrate application ( $\left.100 \mathrm{~g} / \mathrm{vine}\right)$ on dry weight, total $\mathrm{N}$, and fertilizer-derived $\mathrm{N}$ in 'Seyval blanc' vines.

\begin{tabular}{|c|c|c|c|c|c|}
\hline \multirow{3}{*}{$\begin{array}{l}\text { Application } \\
\text { time }\end{array}$} & \multirow{3}{*}{$\begin{array}{c}\text { Dry wt } \\
\text { (kg/vine) }\end{array}$} & \multicolumn{4}{|c|}{ Nitrogen } \\
\hline & & \multicolumn{2}{|c|}{ Total } & \multicolumn{2}{|c|}{ Fertilizer-derived } \\
\hline & & $\%$ dry wt & g/vine & $\%$ of total & g/vine \\
\hline \multicolumn{6}{|c|}{ Trunk and cordons } \\
\hline Budbreak & 1.65 & 0.35 & 5.9 & 3.7 & 0.21 \\
\hline Bloom & 2.11 & 0.35 & 7.2 & 4.5 & $0.33^{*}$ \\
\hline \multicolumn{6}{|c|}{ Shoots } \\
\hline Budbreak & 0.86 & 0.68 & 5.9 & 6.0 & 0.36 \\
\hline Bloom & 1.13 & 0.60 & 6.7 & 6.9 & 0.45 \\
\hline \multicolumn{6}{|c|}{ Leaves } \\
\hline Budbreak & 0.90 & 1.77 & 16.0 & 6.3 & 0.94 \\
\hline Bloom & $1.30^{* *}$ & 1.86 & $24.3^{*}$ & 7.5 & $1.78^{* *}$ \\
\hline \multicolumn{6}{|c|}{ Roots } \\
\hline Budbreak & 0.74 & 0.69 & 5.1 & 5.3 & 0.26 \\
\hline Bloom & $1.00^{*}$ & 0.67 & $6.7^{*}$ & 3.6 & 0.24 \\
\hline \multicolumn{6}{|c|}{ Fruit } \\
\hline Budbreak & 1.48 & 0.70 & 10.3 & 7.1 & 0.68 \\
\hline Bloom & 1.69 & 0.70 & 11.9 & 7.7 & 0.94 \\
\hline \multicolumn{6}{|c|}{ Thinned clusters } \\
\hline Budbreak & 0.05 & 3.05 & 1.5 & 1.8 & 0.03 \\
\hline Bloom & 0.05 & --- & --- & -- & --- \\
\hline \multicolumn{6}{|c|}{ Whole vine } \\
\hline Budbreak & 5.63 & --- & 43.1 & 5.8 & 2.49 \\
\hline Bloom & 7.23 & --- & $56.9^{*}$ & 6.5 & 3.72 \\
\hline \multicolumn{6}{|c|}{ Vineyard floor vegetation } \\
\hline Budbreak & 2.35 & 1.18 & 27.7 & 13.0 & 3.61 \\
\hline Bloom & 2.56 & 1.00 & 25.6 & 20.2 & 5.17 \\
\hline
\end{tabular}

${ }^{*, * *}$ F test significant at $P \leq 0.05$ or 0.01 , respectively.

(Fig. 2). Absorption closely paralleled the pattern of vine dry-matter accumulation (Fig. 1) and was very similar to the pattern of $\mathrm{N}$ uptake by 'Riesling' under German conditions (Lohnertz, 1991) and 'Thompson Seedless' in California (Williams, 1991).

Vines lost $34 \mathrm{~g} \mathrm{~N}$ during the four weeks between harvest and the beginning of leaf senescence, with $21 \mathrm{~g}$ of this $\mathrm{N}$ being removed in the harvested fruit. How the remaining $13 \mathrm{~g}$ was lost from vegetative tissues (roots, trunk, shoots, leaves) is not clear. Although the last vines were excavated before leaf abscission began, some $\mathrm{N}$ may have been lost if leaves abscised before the last sampling. Also, since not all roots were recovered when vines were excavated, changes in the $\mathrm{N}$ content of the whole root system were not measured. Generally, most roots $>5 \mathrm{~mm}$ in diameter were recovered, but many finer roots were not accounted for.

The apparent loss of $\mathrm{N}$ from 'Concord' vines during the postharvest period contrasts with studies on potted $V$. vinifera vines in South Africa, where 27\% (Conradie, 1980) to $34 \%$ (Conradie, 1986) of the annual N absorption occurred between harvest and leaf abscission. This contrast may reflect the fact that the postharvest growing period in cool regions, such as Michigan, is much shorter than in warmer locations, such as South Africa. In Michigan, the first killing frost usually occurs shortly after 'Concord' harvest in early October, so the leaf canopy is typically functional only for a short period of time thereafter. A functional canopy may be present for up to several months after harvest in South Africa (Conradie, 1991). The Michigan 1991 season was unusually warm and harvest occurred 3 to 4 weeks earlier than normal.

'Seyval blanc' vines absorbed a small percentage of ${ }^{15} \mathrm{~N}$-labeled ammonium nitrate applied at budbreak $(7.1 \%)$ or bloom $(10.6 \%)$ relative to other studies where grapevines recovered $14 \%$ to $50 \%$ of applied $\mathrm{N}$ during one season (Conradie, 1986; Williams, 1991). Several factors likely contributed to the low recovery. First, fertilizer was applied uniformly throughout the vineyard floor, simulating a broadcast application. Labeled fertilizer in other studies was applied in a ring beneath vines (Conradie, 1986) or to simulate application through furrow or trickle irrigation systems (Williams, 1991). We observed in excavating vines that the majority of roots were located within the vine row in the weed-free area. Vines likely had little opportunity to absorb $\mathrm{N}$ that was applied between the vine rows. Efficiency might be increased by banding fertilizer beneath vines where most roots were located.

High soil N levels may have contributed to the low recovery of fertilizer $\mathrm{N}$ by vines. Fertilizer $\mathrm{N}$ likely accounted for a small percentage of the total $\mathrm{N}$ absorbed by the vines. The dry weights of 'Seyval' (5.6 to $7.2 \mathrm{~kg}$ ) and 'Concord' vines in the first study $(5.6 \mathrm{~kg})$ were similar. Assuming that the 'Seyval' and 'Concord' vines also absorbed similar amounts of total $\mathrm{N}$ (57 g/vine), fertilizer $\mathrm{N}$ would represent only $4 \%$ to $7 \%$ of the total $\mathrm{N}$ absorbed during the season. This quantity suggests that native soil $\mathrm{N}$ levels were relatively high and may have contributed to the low recovery by diluting fertilizer $\mathrm{N}$ in the soil. If soil $\mathrm{N}$ levels exceed crop demand, percent recovery of fertilizer $\mathrm{N}$ will be low (Weinbaum et al., 1992).

Rainfall received during the three weeks following ${ }^{15} \mathrm{~N}$ applications at budbreak (11 $\mathrm{mm}$ ) and bloom $(20 \mathrm{~mm})$ was not sufficient to reduce recovery by leaching fertilizer $\mathrm{N}$ beyond the vine root system. Average daily temperatures during these periods were relatively low following the budbreak application (12.0C) and warmer following bloom (17.8C). 
Ammonium-N left on or near the soil surface during warm weather potentially can be volatilized and lost as ammonia gas. Although only about half of the applied $\mathrm{N}$ was in the ammonium form, some volatilization could have occurred and contributed to the low recovery of fertilizer $\mathrm{N}$ by vines.

The total amount of fertilizer $\mathrm{N}$ absorbed by vines following applications at budbreak $(2.49 \mathrm{~g})$ and bloom (3.72 g) was not statistically different, although bloom applications resulted in higher fertilizer $\mathrm{N}$ in trunks and cordons and in leaves (Table 1). Greater uptake might be expected from applications at bloom, since the $\mathrm{N}$ demand of vines between budbreak and bloom is believed to be minimal (Conradie, 1991), and summer and fall applications appeared more efficient than applications at budbreak on vines in California, based on relative tissue concentrations (Peacock et al., 1989). Generally, woody perennial plants do not begin absorbing $\mathrm{N}$ efficiently until after rapid shoot growth begins (Weinbaum et al., 1978). However, $\mathrm{N}$ applied at budbreak in this study may have remained available until rapid growth commenced, since rainfall was not sufficient to leach $\mathrm{N}$ from the root zone.

Plant biomass (vines plus vineyard floor vegetation) retained more fertilizer $\mathrm{N}$ following applications at bloom than budbreak. Vineyard floor vegetation competes with grapevines for N (Tan and Crabtree, 1990) and may have reduced overall $\mathrm{N}$ recovery by these vines. Grass in the row middles was actively growing and 20 to $30 \mathrm{~cm}$ tall at bloom, and growing slowly and 5 to $15 \mathrm{~cm}$ tall at budbreak. Nitrogen retained in vegetation on the vineyard floor may be released eventually from plant residues and potentially available to vines in subsequent years.

These studies indicate that vigorous 'Concord' grapevines in Michigan absorbed relatively large amounts of $\mathrm{N}$ (50 to $60 \mathrm{~g} / \mathrm{vine}$ ) during the growing season. The most rapid absorption occurs during active shoot growth in June, July, and August. Vines appeared to lose $\mathrm{N}$ between fruit harvest and leaf senescence. By fall, vines had absorbed only $7 \%$ to $11 \%$ of fertilizer $\mathrm{N}$ applied the previous spring. This low percentage of recovery likely reflects the specific application method and vineyard and climatic conditions of the study.

\section{Literature Cited}

Anton, E.C., J.L. Barnickol, and D.R. Schnaible. 1988. Nitrate in drinking water report to the legislature. Rpt. no. 88-11WQ. Div. of Water Quality State Water Resource Board, Sacramento, Calif.

Conradie, W.J. 1980. Seasonal uptake of nutrients by Chenin blanc in sand culture: I. Nitrogen. S. Afr. J. Enol. Viticult. 1:59-65.

Conradie, W.J. 1986. Utilization of nitrogen by the grape-vine as affected by time of application and soil type. S. Afr. J. Enol. Viticult. 7:76-83.

Conradie, W.J. 1991. Translocation and storage of nitrogen by grapevines as affected by time of application. Proc. Intl. Symp. on Grapes and Wine, 18-19 June, Seattle. Amer. Soc. Enol. Viticult., Davis, Calif. p. 32-42.

Lohnertz, O. 1991. Soil nitrogen and the uptake of nitrogen by grapevines. Proc. Intl. Symp. on Grapes and Wine, 18-19 June, Seattle. Amer. Soc. Enol. Viticult., Davis, Calif. p. 1-11.

Peacock, W.L., L.P.Christensen, andF.E. Broadbent. 1989. Uptake, storage and utilization of soilapplied nitrogen by Thompson Seedless as af- fected by time of application. Amer. J. Enol. Viticult. 40:16-20.

Schaller, K. 1991. Ground water pollution by nitrate in viticultural areas. Proc. Intl. Symp. on Grapes and Wine, 18-19 June, Seattle. Amer. Soc. Enol. Viticult., Davis, Calif. p. 12-22.

Tan, S. and G.D. Crabtree. 1990. Competition between perennial ryegrass sod and 'Chardonnay' wine grapes for mineral nutrients. HortScience 25:533-535.

Weinbaum, S.A., R.S. Johnson, and T.M. DeJong. 1992. Causes and consequences of overfertilization in orchards. HortTechnology 2:112-121.

Weinbaum, S.A., M.L. Merwin, and T.T. Muraoka 1978. Seasonal variation in nitrate uptake efficiency and distribution of absorbed nitrogen in non-bearing prune trees. J. Amer. Soc. Hort. Sci. 103:516-519.

Wermelinger, B. and W. Koblet. 1990. Seasonal growth and nitrogen distribution in grapevine leaves. Vitis 29:15-26.

Williams, L.E. 1987a. Growth of 'Thompson Seedless' grapevines: I. Leaf area development and dry weight distribution. J. Amer. Soc. Hort. Sci. 112:325-330.

Williams, L.E. 1987b. Growth of 'Thompson Seedless' grapevines: II. Nitrogen distribution. J. Amer. Soc. Hort. Sci. 112:330-333.

Williams, L.E. 1991. Vine nitrogen requirementsUtilization of $\mathrm{N}$ sources from soils, fertilizers and reserves. Proc. Intl. Symp. on Grapes and Wine, 18-19 June, Seattle. Amer. Soc. Enol. Viticult., Davis, Calif. p. 62-66.

Williams, L.E. and P.J. Biscay. 1991. Partitioning of dry weight, nitrogen, and potassium in Cabernet Sauvignon grapevines from anthesis until harvest. Amer. J. Enol. Viticult. 42:113-117.

Williams, L.E. and R.J. Smith. 1991. The effect of rootstock on the partitioning of dry weight, nitrogen and potassium, and root distribution of Cabernet Sauvignon grapevines. Amer. J. Enol. Viticult. 42:118-122. 